Original Article

\title{
Homeopathic remedies in a semi-intensive alternative system of broiler production
}

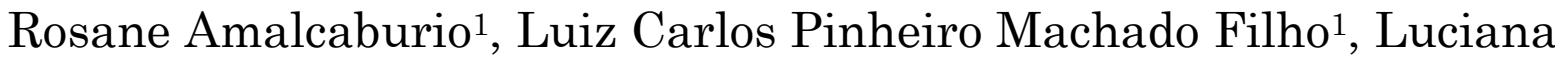 \\ Aparecida Honorato ${ }^{1}$, Nelton Antônio Menezes²
}

(1) Federal University of Santa Catarina, Brazil, (2) EPAGRI, SC, Brazil

\begin{abstract}
This experiment had the objective of evaluating the influence of homeopathic remedies on the performance and health of broilers in a semi-intensive alternative system of production. Two groups of 90 Cobb strain broilers were randomly allocated, at 21 days of life, to three treatments: Control, Calcarea carbonica $12 \mathrm{cH}$ and Calcarea phosphorica $12 \mathrm{cH}$, in a randomized block design in two stages. The medication was administered in the birds' drinking water with a $5 \%$ hydroalcohol extract solution in 5 drops per bird daily during 28 days, beginning at 22 days of age. Each stage comprised three blocks, totalizing six replications per treatment. Each treatment group consisted of 10 broilers. Birds were weighed at 21 days and weekly thereon, up to slaughter at 49 days. After slaughtering, carcasses, hearts, livers, gizzards and feet were also weighed. Differences among stages in weight gain (Stage $1=2,576 \pm 38$ g; Stage $2=2,825 \pm 38$ g; $\mathrm{P}<0,0004$ ) and in final weight (Stage $1=3,470 \pm 38 \mathrm{~g}$, Stage $2=3,348 \pm 40 \mathrm{~g} ; \mathrm{P}<0.03$ ) were noted. There were no differences between stages or treatments for the variables of carcass, feet and gizzard weights $(\mathrm{P}>0.40)$. The liver and heart, however, weighed significantly more in stage 2 $(\mathrm{P}<0.01)$, which may be interpreted as an indicator of greater metabolic activity of these organs coincident with greater weight gain within the same period. When compared to the other two treatments, liver weight proved lower $(\mathrm{P}<0.05)$ in the Calcarea carbonica treatment group, as expected and in accordance to reports of the materia medica of this medicine. In conclusion, there was no effect of homeopathy applied for the purpose of growth. Lower liver weights of the Calcarea carbonica-treated birds may be associated to a lower susceptibility to stress. This possibility, however, calls for new studies for verification.
\end{abstract}

Keywords: Homeopathy, Poultry production, Agroecology.

\section{Introduction}

Homeopathic products are being increasingly utilized in veterinary medicine to augment productivity and health indexes of animals. As an example, Soto et al. [1] noted a significant reduction in the mortality rate of piglets at the nursery and growing phases. In poultry production, studies on the application of homeopathic treatments are being performed with a preventive or therapeutic intent. Vizzani and Novelli [2] demonstrated the homeopathic effect of promoting growth in chickens, where homeopathic products had a similar or superior outcome to that of conventionally used antimicrobial drugs.

Beneficial results of veterinary homeopathy have been revealed on broiler growth, promoting superior weight gain to control groups [3, 4], and on epidemic control. Saad [5] reported the control of an epidemic outbreak of Newcastle disease on Broilers utilizing Belladonna 9cH and nosode (a remedy prepared from brain and trachea tissues of infected birds). The same author compared conventionally to homeopathically treated groups of broilers. Results attested greater weight gain and lower accumulated mortality rates in 53-dayold birds of the homeopathically treated group [6]. Likewise, Linares et al. [7] evaluated the effect of a homeopathic treatment with Calcarea carbonica, Calcarea phosphorica and Calcarea fluorica on average weight, homogeneity, disease resistance and mortality in groups of layer hens and, in comparison to the control group, obtained excellent results. 
Further studies have corroborated the use of homeopathy for the reduction of stress in birds, by means of behavioral observations. Oba et al. [8] examined the use of Hypericum perforatum for the treatment of stress in pullets and observed that birds were calmer and yet provided better feed conversion rates. Estrada et al. [9] compared the utilization of Sulphur $202 \mathrm{cH}$ and antibiotics in the treatment of mycoplasmosis in layer chickens, where the cure rate was significantly higher in homeopathically treated birds than in birds treated with antibiotics.

Nonetheless, not all studies on homeopathic applications have achieved similar results. As an example, Velkers et al. [10] did not find differences between treatments with homeopathic remedies or with placebo in Escherichia coli experimentally infected chickens. Chaves et al. [11] evaluated the therapeutic potential of Thuja occidentalis on experimentally infected birds with avian poxvirus and found neither remission nor restriction of the skin lesions promoted by the infection.

Such diverging outcomes call for a revision of methods utilized in the approach of this therapeutics. In order to achieve a desired degree of evidence, further laboratory experiments and clinical trials are required. The present study aims to contribute to research in this area.

On the other hand, use of homeopathy may favor a transition from the conventional broiler "factory farming" model to an agroecological based system. Agroecological research is typically conducted on a small scale [12], and small farmers are more inclined to adopt this type of technology. Indeed, they are in need of a more profitable, environmentally sound alternative, as organic broilers.

Moreover, there is a growing social demand for chicken meat of higher biological quality, understood as antibiotic and coccidiostatics free meat. One of the main constraints for the adoption of organic broiler production by small farmers is the high cost of organic strains, and its lower conversion rate. As a result, parting from available and low cost resources, chicks of industrial genetics were selected. These birds are offered at half the price and have a higher feed conversion rate than free-range strains ("caipiras"). Furthermore, the semi-confined system with access to pasture has the advantages of being a differentiated alternative rearing system, yet suitable for small farmers.

Because industrial strains have been excessively selected for high yield, their organisms are known to be fragile in various aspects of health. Hence, homeopathic remedies were selected as an attempt to mitigate the effects of the genetic selection. The objective of this experiment was to evaluate the influence of homeopathic remedies on the performance and health of broilers in a semiintensive alternative system of production - i.e., one that provides a favorable environment for the manifestation of the natural behavior of birds as well as adequate handling and sanitary conditions.

\section{Methodology}

The experiment was carried out in the Avian Husbandry sector of the Center of Agricultural Sciences of the Federal University of Santa Catarina, in the city of Florianópolis, Santa Catarina, Brazil (Centro de Ciências Agrárias UFSC). It was performed in two stages: the first was implemented from $12 / 27 / 2007$ to $01 / 31 / 2008$ and the second from $02 / 14 / 2008$ to $03 / 20 / 2008$.

The experimental design was of randomized blocks, with three treatments. Each group of three levels constituted a block, where treatments were randomly allocated. There were, thus, three blocks in each stage, totalizing six repetitions per treatment. Each replication ran with a group of 10 broilers.

Two groups of 90 cockerels (Gallus gallus) of the commercial Cobb strain were utilized. One-day-old birds were received and housed in an installation prepared for this purpose (a brooder) up to 21 days, where they were fed a medicated starter feed with antimicrobials. After 21 days of age, birds were administered a feed without antimicrobials, weighed and transferred to pens, where they were randomly allocated to one of the following three treatments:

CN: control group;

CC: homeopathically treated group with Calcarea carbonica $12 \mathrm{cH}$;

CP: homeopathically treated group with Calcarea phosphorica $12 \mathrm{cH}$.

Homeopathically treated birds received medication in their drinking water, in a 5\% hydro-alcohol extract solution. Daily dosage was 5 drops per bird. Doses were administered during a period of 28 days, from 22 days of age on. The control group received no medication. Medications were prepared by Dermus Homeopathic Pharmacy in accordance to the established technical norms of Farmacopéia Homeopática Brasileira [13].

In this study Calcarea carbonica and Calcarea phosphorica were chosen due to the similitude this particular strain of birds presented to symptoms registered in homeopathic materia medica, with the objective of providing a therapeutic preventive action while maintaining zootechnical performance. This particular strain of birds presents a tendency for rapid growth, slow movements, bone deformations and obesity. The animals are easily frightened and are quite 
sensitive to climatic variations. Once dealing with homogeneous genetic material, these characteristics become common to the whole flock and should, therefore, be taken into account when choosing medications for the collective therapeutic or preventive treatment of the strain.

All animals were vaccinated against Marek's disease and infectious bronchitis on their first day of life at the very hatchery that supplied the birds. Besides experimental animals, at each stage, an extra lot of 30 birds was made available for the replacement of those either dead or affected by infirmities.

Analyzed variables were: Ponderal development (measured by means of individually weighing the birds at 21 days and once a week, up to slaughtering at 49 days of life), Feed conversion (measured by means of weighing feed intake from 1 to 49 days of life), Carcass and organ weights (after slaughtering, carcasses, hearts, livers, gizzards and feet were individually weighed) and Bird health (measured by means of morbidity and mortality indexes of the chickens). The variables of ponderal development, carcass and organ (liver, heart, gizzard and feet) weights were submitted to an analysis of variance with GLM procedure of SAS [14] statistical program. Block, treatment and period (stage) factors were tested in the model.

\section{Results}

There were differences between stages for the variable of ponderal development, however, without treatment interactions. In the second stage, weight gain was significantly higher than stage 1 (Stage $1=2,576 \pm 38$ g; Stage $2=2,825 \pm$ 38 g; $\mathrm{P}<0.0004$ ), for the animals began from 21 days of age with different weights (Stage $1=893.0$ $\pm 6.1 \mathrm{~g}$, Stage $2=523.0 \pm 9.7 \mathrm{~g} ; \mathrm{P}<0.0001)$. Despite the greater weight gain of birds in stage 2, the latter did not manage to reach the weight recorded at 49 days at the first stage (Stage $1=3,470 \pm 38$ g, Stage $2=3,348 \pm 40$ g; $\mathrm{P}<0.03)$.

There was no difference $(\mathrm{P}>0.10)$ between treatments in growth speed, as well as in initial and final weights of birds $(\mathrm{P}>0.20)$. The three groups arrived at 49 days with an average weight of 3,409 g. Feed conversion, measured for the whole group and in both stages, was $1.80 \mathrm{~kg}$ of feed/kg of live weight.

There were no differences between stages or treatments for the variables of carcass, feet and gizzard weights $(\mathrm{P}>0.40)$. The liver $(\mathrm{P}<0.001)$ and heart $(\mathrm{P}<0.03)$, however, weighed significantly more in stage 2 (Table 1). Liver weight was lower $(\mathrm{P}<0.05)$ in the Calcarea carbonica treatment group, as presented in Table 2 .

Table 1. Average weight of viscera, carcass and feet per experimental stage.

\begin{tabular}{llllll}
\hline Stage & Carcass & Liver & Heart & Gizzard & Feet \\
\hline 1 & 2920,83 & $55,47^{\mathrm{a}}$ & $18,28^{*}$ & 43,33 & 142,13 \\
\hline 2 & 2969,97 & $73,08^{\mathrm{b}}$ & $19,50^{\#}$ & 44,69 & 142,33 \\
\hline \multicolumn{5}{c}{ a,b $(\mathrm{P}<0.001) ;{ }^{*}(\mathrm{P}<0.03)$}
\end{tabular}

Table 2. Average weight of viscera, carcass and feet in the control (CN), Calcarea carbonica (CC) and Calcarea phosphorica (CP) treatments.

\begin{tabular}{llllll}
\hline Treatment & Carcass & Liver & Heart & Gizzard & Feet \\
\hline $\mathrm{CN}$ & 3030,41 & $66^{\mathrm{b}}$ & 19,05 & 45,58 & 144,37 \\
\hline $\mathrm{CC}$ & 3007,55 & $60,63^{\mathrm{a}}$ & 18,67 & 43,88 & 142,87 \\
\hline $\mathrm{CP}$ & 3011,75 & $66,21^{\mathrm{b}}$ & 18,96 & 42,59 & 139,46 \\
\hline \multicolumn{5}{c}{$\mathrm{a}, \mathrm{b}(\mathrm{P}<0.05)$}
\end{tabular}

The total of infirmities was of 7 birds, which corresponds to an overall morbidity index of $3.9 \%$. One case of a respiratory disease, two of locomotor diseases and two cases of predatory attacks occurred in stage 1 . In the second stage, one case of a respiratory and one of a locomotor disease were registered.
Seventeen birds died, corresponding to an overall mortality index of $9.4 \%$. In Stage 1, three deaths were brought on by predators and nine by "sudden death", which may have resulted from caloric stress. In stage 2, one death was the effect of a respiratory disease and four of "sudden death", including caloric stress. There were more incidents of sudden death and locomotor problems in the homeopathically treated groups with Calcarea 
phosphorica than in other treatment groups; however, since overall morbidity and mortality rates were low, this index was not given statistical treatment. All infirm or dead birds were substituted.

\section{Discussion}

Considering that there was no difference between treatments in ponderal development (growth velocity or final weight gain), when compared to the control treatment, the homeopathic remedies did not present any growth promoting effect. These results differ from Briones [3], who recorded a $6.4 \%$ difference in weight gain in homeopathically treated chickens, when compared to a control group (without medication), reared in a confined system. These differences in results may be grounded in constituent methodological differences of the remedies (potencies, mediums and doses) as well as in the differences of rearing systems. On the other hand, Boratto et al. [15] came upon similar results in the final weight gain of antibiotic-, probiotic- or homeopathically treated birds. This does not mean, however, that homeopathic remedies may be utilized as substitutes for the more commonly used inputs of the bird industry. It is in the combination of the differentiated system of production with nonresidual medicamental alternatives that one may find some answers when evaluating zootechnical and sanitary parameters of the flock as a whole.

Even though the birds here analyzed were reared in a semi-confined system, with access to pasture and were thus more exposed to climatic and environmental variations, the obtained feed conversion rate (1.80) was comparable to standard rates found within commercial systems. In conventional systems of husbandry of Cobb strain chickens, ratios of 1.81 at 49 days [16]; of 1.90 at 47 days [17]; of 1.71 [15] and 1.75 [18] at 42 days have been uncovered.

Significant differences between treatments in carcass and organ weights, resulting in smaller livers of the Calcarea carbonica - treated birds, point towards an effect of this remedy on this particular organ. In fact, the hepatic symptoms reported in the materia medica, such as a sensitive liver with pulsating pains, pains in the hepatic region and hepatic colics [19], demonstrate the affinity of the remedy with the organ. According to Bonamin [20] observations of general effects of a homeopathic remedy made a posteriori associated to expectations of effects determined a priori by the pathogenesis indicate coherence and convergence among them.

Various studies reveal different causes that affect organ size, more particularly those of the liver and heart. Heat stress, for example, is associated to weight reduction of organs, probably due to the reduction of metabolic activity [21]. Besides changes in functioning, environmental temperature modifies energy, protein and fat retention in an animal's body and provokes diverse physiological adaptive changes, among them, the size of the organs, since the expenditure of energy by metabolically active tissues, such as livers, intestines and kidneys, is greater than that associated to the carcass [22]. Hence, it is possible that because of this reason, within the present experiment, no difference was found in the weight of the carcasses but of the viscera.

Although the intestine, liver and reproductive tract in laying hens together correspond to merely $4 \%$ of the body weight, these same organs are responsible for $30 \%$ of the total expenditure of energy [23]. As such, the Calcarea carbonica remedy may have assisted in the physiological adaptation of the birds to caloric stress, requiring less energy for the maintenance of the organism and, thus, resulting in a smaller growth of the liver mass.

Homeopathic effects are adaptation effects and, thus, the remedy may have assisted the adaptation to the hypercaloric diet, which, on the other hand, could have provoked hepatic steatosis and congestion. Moreover the use of the remedy in a $12 \mathrm{cH}$ potency corroborates with other studies that argument in favor of the biological effect of highly diluted substances. For example, the activity of high dilutions of histamine on basophil activation was recently confirmed by two independent groups, and the biological activity of high dilutions has been repeatedly observed [24].

Bastide [25] points to particularities of research on high dilutions where contrary effects in accordance to the health conditions of the subjects or to the environmental conditions have been observed in some experimental models. It is well known that only perturbed biological systems can show measurable homeopathic effects, and, according to some authors, it is possible to observe therapeutic but no pathogenetic effects, when using experimental models in rats [26, 27].

Differences between periods, in relation to the weight gain in the initial stage of the experiment, may be attributed to the thermal stress of cold that birds suffered in the second phase, when heavy rains fell and brooder installations were consequently flooded. This was the most probable cause for the lower initial weight of chicks, as they were led to the experimental stage. As a result, the greater increase of weight of the second stage was, in reality, due to a compensatory gain that birds obtained within the period. Compensatory weight gain is defined as an increase in the growth rate following a period of less growth [28] and has been observed by various authors in birds submitted to 
periods of feed restriction [29, 30]. Sugeta et al. [31] have observed a compensatory weight gain in chickens submitted to a $30 \%$ feed restriction between the $8^{\text {th }}$ and $12^{\text {th }}$ days of age, however, arriving at 42 days with weights similar to other chicken fed ad libitum.

The compensatory gain of the birds in stage 2 shows that there was, proportionally, a greater demand of metabolic activity, with a consequent growth of the more active organs of these birds within the process. As such, the relative greater weight of the liver and hearts of the birds in stage 2 may also have been attributed to the cold suffered by the chicks within the period. The increase of organs caused by low temperatures constitutes an animal adaptation, due to a greater metabolic demand, associated to the need for a greater production of body heat [32].

In relation to the birds' health, the occurrence of locomotor problems did not differ among treatments. Such problems are more related to the genetic selection of strains for the purpose of rapid growth than to the rearing system itself. It is important to emphasize that, in general, metabolic syndromes present a $70 \%$ greater rate of occurrence in males than females [33]. Although this experiment was performed merely with cockerels, the incidence rate here encountered was similar to that found in the literature on conventional systems, which is around 2\% [34]. Sudden death, the main cause of deaths confronted within this experiment, is known to have quite variable incidence rates within different countries, ranging from $1.25 \%$ to $9.62 \%$ of the total mortality rate [35]. The results here come upon are similar to those reported in conventional systems.

According to the results of the present experiment, one may consider that, a priori, both additives and antibiotics may be eliminated from the bird feed, when substituted by adequate handling and differentiated installations, such as those which grant animals access to external paddocks, which lessen animal density and which separate animals in small groups. These factors are important for the well being of these birds and for the free manifestation of the natural behaviors of the species, ensuring welfare.

\section{Conclusion}

Lower liver weights of the Calcarea carbonicatreated birds may indicate a better adaptation of the birds to this treatment, notwithstanding the demand for new studies to confirm this effect. The observed weight gain, feed conversion and morbidity and mortality indexes are compatible to the performance these strains have obtained with the use of antibiotics and additives in conventional models of poultry husbandry.

\section{Acknowledgments}

We express our gratitude to CAPES (a Brazilian government research support agency Coordinating Body for Training University-Level Personnel); to EPAGRI-SC (Enterprise for Agricultural Research and Rural Extension of the State of Santa Catarina, Brazil); to Patrícia Tomazini Medeiros and to the Agroindustrial Company Macedo Ltd.; to the trainees of the LETA (Laboratory of Applied Ethology, UFSC), Aline Freitas de Melo, Daíse Werncke, Ísis Caramez and Natália Adan; and finally to Dr. Maria J. Hötzel (UFSC) for her valuable comments.

\section{References}

[1] Soto FRM, Vuaden ER, Benites NR, Azevedo SS, Pinheiro SR, Bernardi F, et al. Implantação da homeopatia e avaliação dos índices de produtividade de uma granja comercial de suínos comparado com a alopatia na fase de recria e terminação. Vet e Zootec. 2007; 14(1): 107-144.

[2] Vizanni A, Novelli A. The effect of using homoeopathic remedies as growth promoters in poultry. Proceedings of the Omeomed' 92: First International Congress. The Homeopathic Medicine in Europe; 1993. Urbino, Italy. Urbino: Physical-Chemical-Biological and Clinical Research. Urbino. p 175-178.

[3] Briones SF. Ensayos en pollos "broiler". Estudios sobre la Aplicación de Homeopatía en Producción Animal [book online]. Santiago (Chile); 1987 [cited 2009 Mar 19]. [about 2 p]. Available from: http://homeoint.org/articles/brioanim/index.htm\#br oiler.

[4] Ahumada C, Briones SF, Cubillos S, Rubio F. Ensayo en pollos "broiler": Ensayo $\mathrm{n}^{0} 1$ to 3 . Estudios sobre la Aplicación de la Homeopatía en Producción Animal [book online]. Santiago (Chile); 1987 [cited 2009 Mar 19]. [about 2 p]. Available from:http://homeoint.org/articles/brioanim/index.ht m\#broiler.

[5] Saad S. Tratamiento homeopático en un lote de pollos parrilleros afectados de enfermedad de Newcastle. Homeopatía. 1990; 55(1): 13-14.

[6] Saad S. Experiencia con una crianza completa de pollos parrilleros tratados con homeopatía. Homeopatía. 1990; 55(1): 9-11.

[7] Linares F, Pérez B, Gascón A. Homeopatia en la Agricultura. Promotor de crecimiento em inicio reemplazo ponedora. Proceedings of the XII Fórum de Ciência y Técnica; 1997. Santa Clara, Cuba; Havana: 1997. p 15-18.

[8] Oba A, Lonni AASG, Guimarães IG, Waine J, Duarte JC, Munhoz VM. Homeopatia para o tratamento de estresse de aves de reposição. 
Proceedings of the I Congresso de Farmácia de Maringá; 2006; Maringá, Brazil. Maringá: Universidade Estadual de Maringá; 2007. p 84.

[9] Estrada C, Osmaida Catala BF, Brazaga GR. Evaluación del efecto del Sulphur 202CH y el Polistar contra la Micoplasmosis en ponedora comercial. Agro y Veterinaria [online]. 2008 [cited 2008 Jul 25]. Available from: www.vetuy.com/articulos/avicultura/index avic.htm.

[10] Velkers FC, Te Loo AJH, Madin F, Van Eck JHH. Isopathic and pluralist homeopathic treatment of commercial broilers with experimentally induced colibacillosis. Res Vet Sci. 2005; 78: 77-83.

[11] Chaves TCB, Bernardo AR, Sanavria A, Brito MF, Da Cruz GB, Danelli MGM. Ineficiência da Thuja occidentalis no tratamento dos poxvirus aviários. Ciência Rural. 2006; 36(4): 1334-1336.

[12] Dalgaard T, Hutchings NJ, Porter JR. Agroecology, scaling and interdisciplinarity. Agr Ecosyst Environ, 2003; 100: 39-51.

[13] Farmacopéia Homeopática Brasileira. $2^{\mathrm{a}}$ ed. São Paulo (Brazil): Atheneu Editora; 1997.

[14] SAS. SAS User's Guide: Statistics. Cary (United States): SAS Inst Inc; 1989.

[15] Boratto AJ, Lopes DC, Oliveira RF, Albino LFT, Sá LM, Oliveira GA. Uso de Antibiótico, de Probiótico e de Homeopatia, em Frangos de Corte Criados em Sistema de Conforto, Inoculados ou não com Escherichia coli. Rev Bras Zootec. 2004; 33(6): 1477-1485.

[16] Granja Planalto Ltda. Manual do Frango de Corte. Uberlândia: Granja Planato Ltda; 2006 Jul 18. Report No: 03.

[17] Flemming JS, Janzen SA, Endo MA. Teste com linhagens comerciais de frango de corte Avaliação dos parâmetros zootécnicos. Arch Vet Sci. 1999; 4(1): 57-59.

[18] Medeiros PT. Produção Avícola: Subsídios na busca de sistemas de alimentação saudáveis, econômicos e de menor impacto ambiental [Thesis Master]. Florianópolis: Centro de Ciências Agrárias, Universidade Federal de Santa Catarina; 2008.

[19] Lathoud, JA. Matéria médica Homeopática. Buenos Aires (Argentina): Editorial Albatroz; 1980.

[20] Bonamin LV. Dados experimentais que fundamentam teorias interpretativas sobre ultradiluições. Tributo a Madeleine Bastide. Cultura Homeopática, 2007; 21: 29-35.

[21] Plavnik I, Yahav S. The effect of environmental temperature on broiler chickens subjected to growth restriction at an early age. Poult Sci. 1998; 77: 870-872.

[22] Baldwin RL, Smith NE, Taylor J, Sharp M. Manipulating metabolic parameters to improve growth rate and milk secretion. J Anim Sci. 1980; 51: 1416-1428.

[23] Sprat RS, McBride BW, Bayley HS, Leeson S. Energy metabolism of broiler breeder hens. Contribution of tissues to total heat production in fed and fasted hens. Poultry Sci. 1990; 69(8): 13481356.

[24] Sainte-Laudy J, Belon P. Improvement of flow cytometric analisys of basophile activation inhibition by high histamine dilutions. A novel basophile specific marker: CD 203 c. Homeopathy. 2005; 95: 3-8.

[25] Bastide M. Teorias interpretativas sobre as ultradiluições e evidências a favor. Cultura Homeopática. 2006; 16: 22-30.

[26] Coelho CP, D'Almeida V, Pedrazzolli-Neto M, Duran-Filho C, Florio JC, Zincaglia LMC, Bonamin LV. Therapeutic and pathogenetic animal models for Dolichos pruriens. Homeopathy. 2006; 95: 136-143.

[27] Pinto SAG, Bohland E, Coelho CP, Morgulis MSFA, Bonamin LV. Na animal model for the study of Chamomilla in stress and depression: pilot study. Homeopathy, 2008; 97: 141-144.

[28] Yu MW, Robinson FE, Clandini MT, Bodnar L. Growth and body composition of broiler chickens in response to different regimens of feed restriction. Poultry Sci. 1990; 69(12): 2074-2081.

[29] Giachetto PF. Mecanismos hormonais do ganho compensatório e composição de carcaça em frangos de corte submetidos a restrição alimentar com diferentes níveis energéticos [Thesis Master]. Jaboticabal: Faculdade de Ciências Agrárias e Veterinárias, Universidade Estadual Paulista; 1998.

[30] Zubair AK, Leesson S. Effect of varying period of early nutrient restriction on growth compensation and carcass characteristics of male broilers. Poultry Sci. 1994; 73(1): 129-136.

[31] Sugeta SM, Giachetto PF, Malheiros EB, Macari M, Furlan RL. Efeito da restrição alimentar quantitativa sobre o ganho compensatório e composição da carcaça de frangos. Pesq Agropec Bras. 2002; 37(7): 903-908.

[32] Oliveira GAO, Oliveira RFM, Donzele JL, Ceco PR, Vaz RGMV, Orlando UAD. Efeito da temperatura ambiente sobre o desempenho e as características de carcaça de frangos de corte dos 22 aos 42 dias. R Bras Zootec. 2006; 35(4): 13981405. 
[33] Olkowski AA, Classen HL. Sudden death syndrome in broiler chickens: a review. Poultry Avian Biol Rev. 1995; 6: 95-105.

[34] Gonzales E, Mendonça Jr CX. Problemas locomotores em frangos de corte. Proceedings of the VII Simpósio Brasil Sul de Avicultura; 2006 Apr 4-6; Chapecó, Brazil. Chapecó: Núcleo Oeste de Médicos Veterinários; 2006. p 79-94.

\section{(c)) BY-NC-ND Licensed to GIRI}

\section{Support: CAPES, EPAGRI-SC}

Conflict of interest: authors declare there is no conflict of interest

Received: 17 Jan 2009; Revised 17 Mar 2009; Published: 31 Mar 2009

Correspondence author: Luiz Carlos Pinheiro Machado Filho, pinheiro@cca.ufsc.br

How to cite this article: Amalcaburio R, Machado Filho LCP, Honorato LA, Menezes NA. Homeopathic remedies in a semiintensive alternative system of broiler productio. Int J High Dilution Res [online]. 2009 [cited YYYY Month dd]; 8 (26): 33 39. Available from: http://www.feg.unesp.br/ ojs/index.php/ijhdr/article/view/325/383. 